\title{
An Empirical Research on Consumer Innovativeness in Relation with Hedonic Consumption, Social Identity and Self-Esteem
}

\author{
Deniz Maden \\ Research Assistant \& PhD Candidate \\ Faculty of Communications, Ege University, Turkey \\ deniz.maden@ege.edu.tr \\ Dr. Nahit Erdem Köker \\ Assistant Prof. Dr., Faculty of Communications \\ Ege University, Turkey \\ nahit.koker@ege.edu.tr
}

Doi:10.5901/jesr.2013.v3n7p569

\begin{abstract}
Consumer innovativeness indicates the the degree of consumers' tendency to buy new products, services or brands. The focus of this research is the relation of consumer innovativeness with hedonic consumption, social identity and self-esteem. With the purpose of detecting the relations of hedonic consumption, self identity and self-esteem with consumer innovativeness, a quantitative research has been carried out. The survey instrument has been formed by using four scales from the existing literature. The universe of the research has been detected as the students of University of Turin - Italy. Due to the fact that the universe comprised of Italians, the survey instrument was translated from its original language English to Italian by using the methods of back-translation and pre-test. In accordance with the descriptional and relational model of research, several tests were applied to the data using SPSS and Lisrel. Finally results have been analyzed and discussed.
\end{abstract}

Keywords: Consumer innovativeness, innovation diffusion, hedonic consumption, social identity, self-esteem.

\section{Introduction}

Recently within the field of marketing, innovation has been one of the most popular research topics. "An innovation is an idea, practice, or object that is perceived as new by an individual or other unit of adoption (Rogers, 1995: 11)". Many innovation studies are directed to the emergence of a new product, service or a process. In other words, they are directed to the innovation itself. Along with innovation studies which focus on the innovation itself, another critical field of study is consumers' adoption of innovations. Right at this point, the issue of consumer innovativeness emerges. Consumer innovativeness indicates the the degree of consumers' tendency to buy new products, services or brands.

Consumer innovativeness has a relation with many factors such as need for uniqueness (Roehrich, 2004), quality, attributes, social environment (Gladwell, 2000), characteristics of adopters (Glanz, 2008), intrinsic motivations (Fishben, 1975; Ajzen, 1991; Davis,1989), innovations' own characteristics (Greenhalg et.al, 2004; Rogers, 2003; Wejnert, 2002), characteristics of individuals (Rogers, 2003; Silverman, 2011), culture (Daghfous, Petrof \& Pons,1999) and nationality (Lynn \& Gelb, 1996). Within the scope of this research, it has been hypothesized that hedonic consumption, self-identity and self-esteem have a relation with consumer innovativeness. The hypotheses were empirically tested and evaluated.

\section{Literature Review and Hypotheses Development}

In the literature review of the study, the concepts of consumer innovativeness, hedonic consumption, self identity and self-esteem are revealed. Evidence from existent research have been cited to understand these concepts and their relation with other factors which influence consumer behaviour and innovativeness. Finally, hypotheses of the research have been developed.

\subsection{Consumer Innovativeness}


The success of innovations depends on consumer innovativeness because innovativeness introduces the innovation to the social system (Grewal, Mehta \& Kardes, 2000: 234) and thereby determines innovations' acceptance by targets. "Consumer innovativeness, or consumption of newness is the tendency to buy new products more often and more quickly than other people (Midgley \& Dowling, 1978 as cited in Roehrich, 2004: 671)". Consumer innovativeness connotes to the early purchase of a new product (Cestre, 1996), but is also considered as having the tendency to be attracted by new products (Steenkamp et al., 1999 as cited in Roehrich, 2004: 671)". What is meant by consumer innovativeness is how consumers embrace innovation. In other words, it indicates the adoption status and personal closeness to innovation. Theories of innovation diffusion have been used to explain consumers' adoption to innovative products. It is important to clear out what is meant by 'diffusion'. Diffusion is the process by which an innovation is communicated through certain channels over time among the members of a social system (Rogers, 1995: 6). Hence, there are four main elements in the diffusion of new ideas; the innovation itself, which is communicated through certain channels, over time and among the members of a social system (Rogers, 2003: 36).

Consumers' adoption process to innovations are affected by many factors, thereby several research draw attention on different aspects of diffusion and adoption of innovations. Some researchers have evaluated the concept focusing on intrinsic motivations on the individual level (Fishben, 1975; Ajzen, 1991; Davis,1989) while some focused on developer based theories (Surry, 1997). Some researchers highlighted the strong effects of innovations' own characteristics in the speed and extent of the adoption and diffusion (Rogers, 2003; Greenhalg et.al, 2004; Wejnert, 2002). According to the results of these studies; relative advantage, compatibility, complexity, trialability, and observability turned out to be factors which affect the own characteristics of innovations and thereby the attributes of the diffusion (Glanz, 2008: 319). In some research, the characteristics of individuals have been evaluated as an important factor for the adoption of innovation (Rogers, 2003; Silverman, 2011). Rogers (2003) identified five adopter categories: innovators, early adopters, early majority adopters, late majority adopters and laggards. From 1 to 5 , these adopter categories form a bell shaped curve where innovators are the most inclined to innovations and laggards are the least. Daghfous, Petrof and Pons (1999) state that individuals' adoption of innovations is strongly affected by culture. Daghfous et. al also discoverd a relation between consumer innovativeness and hedonic consumption. According to Goldsmith and Hofacker (1991), there is an effect of individual's personal interest to innovation and emotional bond with it. Waarts and Van (2005) highlight the effects of national culture on the adoption status of innovations.

As seen from the antecedents of existing literature, consumer innovativeness may be related with many concepts. The focus of this research is the relation of consumer innovativeness with hedonic consumption, social identity and selfesteem.

\subsection{Hedonic Consumption}

In the past decades, the hedonic dimension of consumption has been gradually increasing its importance. This is basically grounded on the tremendous increase in brands, products/services and the changing characteristics of consumers. Thus, it is getting almost impossible to attract consumers by depeding only on utilitarian features.

Hedonic consumption is described as "those facets of consumer behavior that relate to the multisensory, fantasy and emotive aspects of one's experience with products (Hirschman \& Holbrook, 1982)". Hedonic consumption is closely related with emotions, rather than rationality. It is associated with concepts such as; pleasure, arousal, fantasies, feelings, fun and the role of the individual (Hopkinson \& Pujari, 1999: 274).

Products used for consumption purposes can be categorized as hedonic or utilitarian (Lim \& Ang, 2008: 226). Hedonic products are defined as those "whose consumption is primarily characterized by an affective and sensory experience of aesthetic or sensual pleasure, fantasy, and fun (Dhar \& Wertenbroch, 2000: 61)". While consuming hedonic products, consumers are more likely to think of enjoyment, excitement, captivation and escapism (Babin et. al., 1994). Utilitarian goods are for practical purposes while hedonic goods exist to fulfill emotions. In the case of utilitarian goods functionality and rationality are important, but for hedonic goods feelings, emotions and experiences gain greater importance. Mano and Oliver (1993) found out that people tend to exhibit stronger affective reactions to hedonic consumption (Roy \& NG, 2012: 82). The main reason beyond this is the emotional attachment, which does not exist for utilitarian products.

Hedonic consumption and hedonic goods have been the subject of various research. In many research, hedonic consumption has been evaluated together with utilitarian consumption (Batra \& Ahtola, 1991; Chaudhuri, 2002; Chitturi et. al., 2007; Dhar \& Wertenbroch, 2010; 2012; Okada, 2005; Roy \& NG). Hedonic consumption has been an important field of research for luxury studies (Allison, 2008; Dubois, Czellar \& Laurent, 2005; Hagtvedt \& Patrick, 2009; Snell \& 
Varey, 1995; Vigneron \& Johnson, 1999). It has been associated with impulsiveness and impulse buying (Tifferet \& Herstein, 2012; Urminsky \& Kivetz, 2003). Some studies on hedonic consumption focused at cultural differences. Evidence from these studies (Burroughs \& Rindfleisch, 2002; Scitovsky, 1976, 1986) suggest that, consumption, of hedonic consumer products, is highly important for happiness among modern consumers, therefore highly developed economies have an increased emphasis on hedonic consumption (Zhong \& Mitchell, 2010: 153). There are also some studies which evaluated the subject within the scope of a sector e.g. wellness, travel, hospitality, wine (Bruwer \& Alant, 2009; Miao, et. al., 2011, 2013; Stoddard, J. E., Evans, M. \& Shao, 2012; Zhong \& Mitchell, 2010). Daghfous, Petrof and Pons (1999) discoverd a relation between consumer innovativeness and hedonic consumption. They noted that consumers with hedonic consumption values can adopt to innovations in a shorter period of time. Carrying on the antecedents of existing research, it is likely that there is a relationship between consumer innovativeness and hedonic consumption.

Hypotheses 1. There is a relationship between consumer innovativeness and hedonic consumption.

\subsection{Social Identity}

Social identity contains information about individuals' commitment and attachment to a specific group and the status and characteristics of this group (Tajfel \& Turner, 1986 as cited in Jacobs, 2013: 44). Social identity function serves as a way to communicate something about the self to others.

According to Hugstad, Taylor and Bruce's (1987) research about effects of social class on consumer information search, consumption is an issue of identity, thereby consumption choices are made in order to become a member of a social class. In this way, the social identity function in consumption generates importance. Consumers are often attracted to products and brands which are linked to their social identity. This tendency results from the fact that consumers are inclined to purchasing brands that symbolize their own personality traits, or brands that represent the person that consumers wish to become (Reed \& Forehand, 2003: 3). Either way, consumers' social identity stands out as an important factor which motivates purchase. By no means, this fact directs marketers to build and position brands according to the characteristics of their target audiences's social identity.

Research have been directed to social identity within the field of consumer behaviour from many perspectives. Jacobs (2013) investigated the relationship between social identities and innovation as a collective art. She focused on how multiple social identity processes create positive commitment and motivation for collaborative innovation. Reed and Forehand (2003) present a framework on how consumers come to socially identify with specific groups, products, and brands, and how and when these social identifications influence reactions to marketing stimuli. Yorno, Postmes \& Haslam (2007) explored the effects of social identity and group norms on the creativity of individuals and groups. They argued that norms influence creativity and and creative endeavor. Research have been directed to social identity based positioning techniques (Forehand \& Deshpandé 2001; Jaffe \& Berger 1988; Shavitt \& Nelson 2000; Wooten 1995). They came up with the result that effective planning of positioning includes to detect the social identities of the target consumers. Grewal, Mehta and Kardes (2000), directed their research to the role of the social-identity function of attitudes in consumer innovativeness and opinion leadership. The results of their study showed that social identity function exerts a strong impact on innovativeness and opinion leadership. The authors cited that innovations are primary for eliciting the social identity function and the social identity function plays an important role in the adoption and diffusion of innovations. Many research have been directed to social identity's influence on organizational behaviour (Ashforth \& Johnson, 2001; Ellemers et. al., 2004; Highhouse et. al., 2007; Massimo \& Bagozzi, 2000; Wieseke et. al., 2008). Within these research, social identity has been evaluated as a function which effects individuals in an organization. Social identity perspective's basic premise is that individuals have a personal identity as well as a range of social identities. Social identity is an aspect of the self which is derived from memberships of social groups of their own values and norms (Yorno, Postmes \& Haslam, 2007: 411). While these values and norms are internalized by the members of the group, they shape people's ideas and influence their behaviour. Thereby, social identity is likely to have an effect on consumer innovativeness. This argument forms the second hypothesis of this research.

Hypotheses 2. There is a relationship between consumer innovativeness and social identity.

\subsection{Self-Esteem}

Self-esteem is an important driver of consumption. Consumers purchase decisions are made within the context of enhancing or protecting self esteem (Grubb \& Grathwohl, 1967 as cited in Banister: \& Hogg, 2004: 850.). A brief 
definition of self-esteem would be, individual's perception of his or her own value. It includes variables as person's likeliness, appreciation, approvement and value given to ownself.

Many studies on consumer behaviour have been directed to self-esteem because it is key construct to understanding human behaviour. Self-esteem has a central role in explaining human psychology which makes it an important factor to designate consumption choices. Consumer behaviour research indicates that acquiring goods help improve self-esteem (Arndt et. al. 2004 as cited in Truong, \& McColl, 2011: 556). Marketing strategies directed to selfesteem need to include self-respect, sense of accomplishment, prestige and fame (Lamb, Hair \& McDaniel, 2012: 219). Many of the luxury brands have contexts related to consumers' self-esteem.

Researchers have came up with some important findings about self-esteem. These include aspects such as: People with high self-esteem are more likely to participate in the affairs around them, mainly due to their confidence, they are more tolerant of deviance, less authoritarian, less anxious and less authoritarian (Lane, 1995: 183). Janis (1954) found that individuals with low self-esteem are more easily influenced by others (Clark \& Goldsmith, 2005: 294). Thereby, suggestions are considered to be more important and effective for individuals with lower self-esteem. Drawing on this fact, it may be argued that individuals with high self-esteem will have a higher level of consumer innovativeness, while individuals with lower level of self-esteem would be more inclined to follow their suggestions and behaviour.

Due to the fact that self-esteem has important effects on influencing consumer behaviour from many aspects, within the scope of this research it is argued that self-esteem may have a relation with consumer innovativeness. This argument generates the third and final hypotheses of this study.

Hypotheses 3 . There is a relationship between consumer innovativeness and self-esteem.

\section{Method}

\subsection{Research Objectives and Model Development}

Objectives of this research are: To describe factors which may have an effect on consumer innovativeness and detect the relations of hedonic consumption, self identity and self-esteem with consumer innovativeness. For these purposes, the research is designed with a descriptive and relational model. While descriptive research models aim at detecting a situation concerning a subject (Erdoğan, 1998:60-61), relational models aim at investigating the relation between variables (iftar, 2000). The research model may be seen in Figure 1.

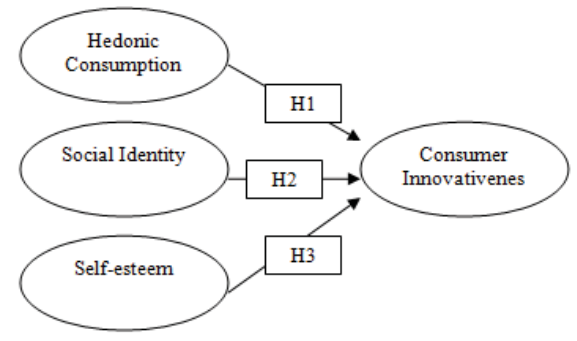

Figure 1: Research Model

\subsection{Measures}

Measures of the research were selected after a detailed literature review on the concepts of consumer innovativeness, hedonic consumption, self identity and self-esteem. Measures used in the research compose of the following scales: Martinez and Montaner's (2005) innovativeness scale, Babin, Darden and Griffin's (1994) scale on hedonic and utilitarian shopping value, social identity function scale of Grewal, et. al (2000) and Rosenberg's(1965) self-esteem scale. Using these scales a questionnaire was formed. The original scales were in English, because of that the participators were Italian, the questionnaire was translated to Italian.

Research instrument's translation is a critical process. "Generally, direct translation of an instrument from one language to another does not guarantee content equivalence of the translated scale (Brislin 1970, Sechrest \& Fay 1972 as cited in (Cha, Kim \& Erlen, 2007: 387)". Therefore, in this research, translation methods suggested by experts were 
used to ensure the validity. Four techniques were offered by Brislin (1970) for maintaining the equivalence between the original and translated measures: back-translation method, bilingual technique, committee approach, pretest procedure. In this research, the back-translation method and the pretest method were used, as it is suggested by experts to combining different translation techniques to overcome limitations of a single technique (Jones et al., 2001). "Researchers agree that back-translation of an instrument is essential for its validation and use in a cross-cultural study (McDermott \& Palchanes 1992, Jones et al. 2001, John et al. 2006 as cited in (Cha, Kim \& Erlen, 2007: 387)". In his well known method, Brislin (1970) recommended a repeated independent translation and a back-translation from different translators. According to his back-translation method, first, a bilingual translator translates an instrument from the original language to the target language. Second, another bilingual translator independently back-translates the intrument from the target language to the original language. Afterwards, the two translations are compared for concept equivalence. Until the errors are eliminated, a third translator retranslates the problematic items (Cha, Kim \& Erlen, 2007: 388). The second translation method used for this research is the pre-test method. This method is a pilot study to foresee any problems which may accure in the clarity of the research instrument.

The research intrument was first translated from english (original language) to Italian (target language) by a bilingual professor who is half Italian and half British. Then, another half Italian and half British bilingual law masters student, did the back-translation of the instrument from the target language to the original language. The two translations were compared for concept equivalance. 3 problematic items accured in this process and they were eliminated with the translation of a bilingual lawyer. After the back-translation, the pretest method was used to make sure that there are no problems with the clarity of the questions. The questionnaires were filled by 60 participants among the sample and it was prooved by the consistency of the answers and low number of missings that there were no misunderstandings of the research instrument.

\subsection{Sample}

The universe of the research was determined as the students of University of Turin - Italy. Then data were collected from the students of University of Turin, using judgement sampling. A total of 283 questionnaires were handed to students face to face, after the elimination of the forms, 279 were used for the analysis. The demographics of the sample may be seen in Table 1.

Table 1: Demographics of the Sample

\begin{tabular}{|c|c|c|c|c|c|}
\hline & Frequencies (F) & $(\%)$ & & Frequency (F) & $(\%)$ \\
\hline Gender & & & Year & & \\
\hline Female & 165 & 59.1 & $\overline{1 s t}$ & 59 & 21.1 \\
\hline Male & 113 & 40.5 & 2nd & 49 & 17.6 \\
\hline Not specified & 1 & 0,4 & 3 rd & 64 & 22.9 \\
\hline \multirow[t]{2}{*}{ Total } & 364 & 100.0 & 4th & 45 & 16.1 \\
\hline & & & Post-graduate & 46 & 16.5 \\
\hline Income & & & Not specified & 5 & 1.8 \\
\hline$<200 €$ & 136 & 48.7 & Total & 279 & 100.0 \\
\hline $201-400 €$ & 51 & 18.3 & & & \\
\hline $401-600 €$ & 19 & 6.8 & & & \\
\hline$>601 €$ & 48 & 17.2 & & & \\
\hline Not specified & 25 & 9.0 & & & \\
\hline Total & 279 & 100.0 & & & \\
\hline
\end{tabular}

\subsection{Findings}

The results of the research have been analyzed using SPSS 17 and LISREL 8.80. First, demographic breakdown, reliability analysis and confirmatory factor analysis were done. After the factor loadings and reliability tests were prooved, further analysis were carried out. Means and standard deviations of dimensions were determined. Finally, multiple regression analysis was applied to test the three hypothesis of research. 
Table 2: Scale Items, Reliability Analysis and Confirmatory Factor Analysis

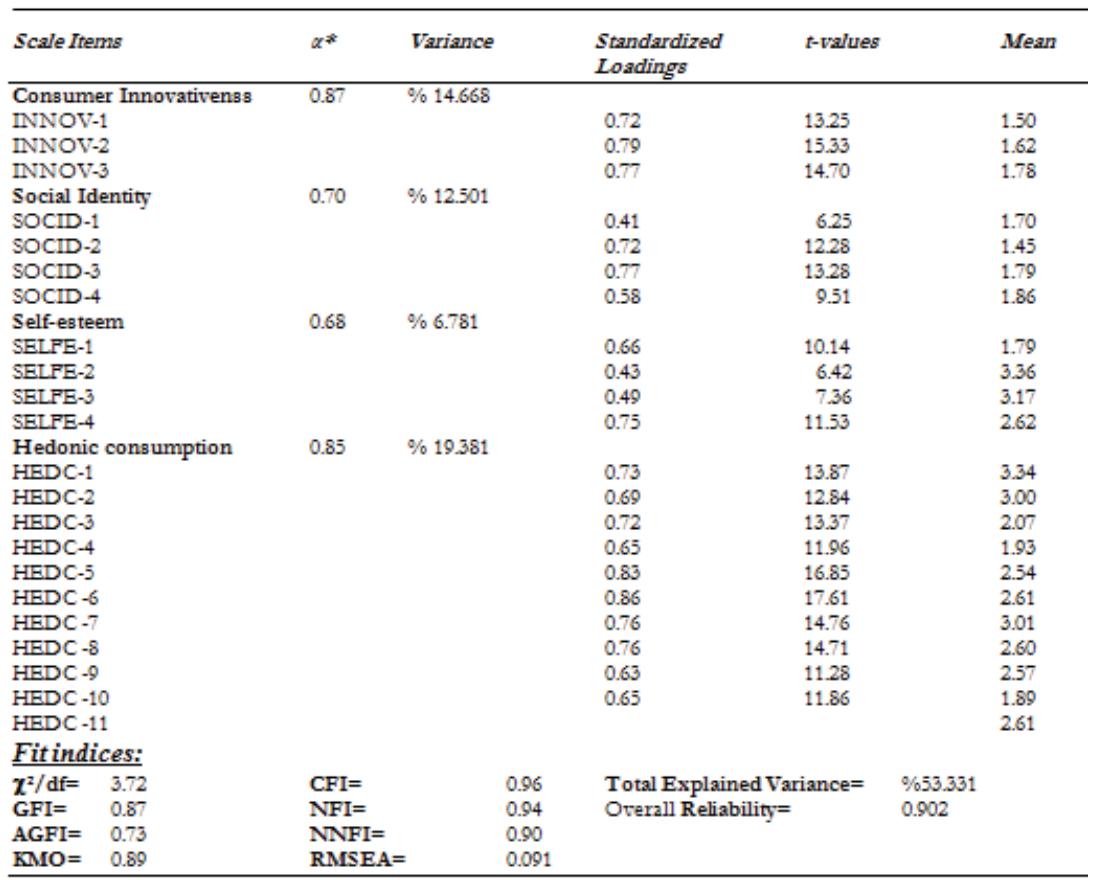

All items were designed on a 5 point likert scale. (5=strongly agree, 1=strongly disagree). A Cronbach Alpha value more than 0.70 prooves the reliability of the scale, but in cases where there are less questions, this value is 0,60 (Sipahi, Yurtkoru, Çinko 2008:89). As seen in Table 2, all factors have Cronbach Alpha values greater than the suggested value of 0.60 .

Table 2 shows the total item correlations and reliability coefficients of this study's dimensions and items. As seen in Table 2, coefficient alfa values for all four factors are between $0.68-0.87$, which means that they are above the level of 0.60 determined by Nunnally and Bernstein (1994). Total item correlations are between $0.35-0.84$, which indicates they are as high as Saxe and Weitz (1982) have suggested (0.32). This prooves that the instrument purveys the minimum standards for collison validity. Also, the ultimitate mean values of all items may be seen in Table 2 . There is no significant problem about the mean values. To be able to see the mean differences, all mean scores for each item have been counted with the mean score related to the item.

Table 3: Means and Standard Deviation

\begin{tabular}{llll}
\hline Dimensions & Means & Standard Deviation & Sig. \\
\hline 1.Consumer Innovativeness & 1.973 & 0.924 & $0.000^{*}$ \\
2.Social Identity & 1.720 & 0.799 & $0.000^{*}$ \\
3.Self-esteem & 2.741 & 0.868 & $0.021^{*}$ \\
4.Hedonic Consumption & 2.578 & 0.854 & $0.001^{*}$ \\
& & & \\
${ }^{*} \mathrm{p}<0.01$ level, ** ${ }^{* *}<0.05$ level & & & \\
\hline
\end{tabular}

As seen in Table 3, the mean value of self-esteem dimension turned out to be the highest (2.741), while the mean value of social identity turned out to be the lowest (1.720). Mean values indicate that consumers are ambivalent about selfesteem and hedonic consumption dimensions while the mean values are higher 2.74 and 2.57, which are close to 3 (neither agree nor disagree). On the other hand, consumers are closer to disagree with consumer innovativeness and social identity dimensions while the mean values are closer to 2 which indicates the state of disagreement.

It is seen in Table 2 and 3 that all mean score differences are evident $(p<0.01)$ and $t$-values are greater than $+/$ - 
2.00 (Nunnally\&Bernstein, 1994; Hair, Money, Samouel\&Page, 2007). Values of standard deviations show that participants are consistent in their answers but do not have sufficient clarity (Tabachnick\&Fidell, 1996). Mean scores of Italian participants were lower than 3.00 which shows that they are more inclined to being ambivalent or in disagreement. Using these composite scores, further analysis of two variabled correlations have been made. Results of this analysis show that all correlations among dimensions are significant in the level of 0.01 . Correlations are between 0.87 (consumer inovativeness) and 0.68 (self-esteem). Lowest level of correlation is seen in social identity and self-esteem and the highest level of correlation is seen in consumer innovativeness (0.87). These results show evidence for the discriminant validity of the scale. Assumptive relations were tested by regression analysis.

The standard deviation is on the highest level for consumer innovativeness and on the lowest level for social identity. Though, there is a small difference between the standard deviations, it may be said that people have more varied opinions on consumer innovativeness while they more likely to agree on social identity.

By regression analysis, the assumptive relationship was tested. Regression analysis "relates a single criteria variable with a one or more dependant variables. While one or more dependant variables are held in a constant level, this criteria calculates the frequency distribution of the variable (Churchill ve lacubucci, 2002: 981).

Table 4: Multiple Regression Analysis

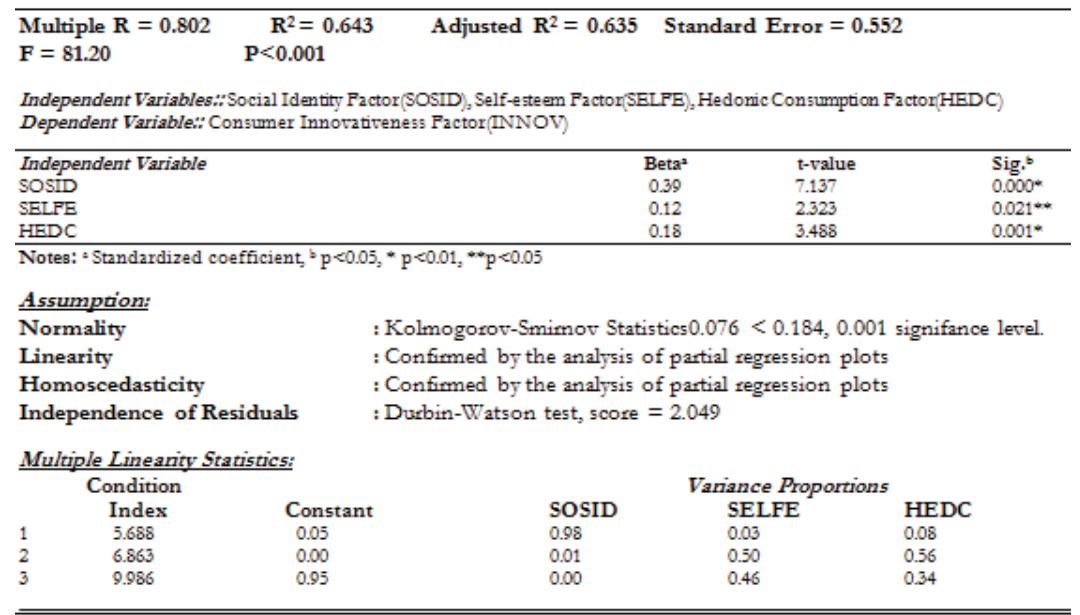

In the multiple regression analysis, social identity, self-esteem and hedonic consumption were independant variables and consumer innovativeness was the dependant valuable. First of all, normality, linearity, homoscedasticity and independence of residuals were tested and the regression analysis was confirmed. Results show that "residuals are normally dispersed according to the expected dependant valuable value. Residuals have a linear line relation with the expected dependant valuable values. Homoscedasticity of residuals' expected dependant valuable values are the same for all expected values (Tabachnick \& Fidell, 1996: 136). Also there is no evidence of multicollinearity problem (Hair vd., 2007) since "...each conditioning index is lower than 30 , and at least two variance proportions are lower than 0.50 " (Tabachnic \& Fidell, 1996: 87). The $\mathrm{R}^{2}$ value shows that $64 \%$ of consumer innovativeness may be explained by social identity, self-esteem and hedonic consumption dimensions.

Significance values for all three independent variables proove a significant relationship with consumer innovativeness while all values are smaller than 0.05 . Therefore, all three hypothesis of this research which have anticipated a relationship between consumer innovativeness and the concepts of self-esteem, hedonic consumption and social identity have been proven right.

\section{Discussion and Implications}

Consumer innovativeness indicates the the degree of consumers' tendency to buy new products, services or brands. The focus of this research was the relation of consumer innovativeness with hedonic consumption, social identity and self- 
esteem. With the purpose of detecting the relations of hedonic consumption, self identity and self-esteem with consumer innovativeness, a quantitative research has been carried out.

The objectives of this research were determined as to describe factors which may have an effect on consumer innovativeness and detect the relations of hedonic consumption, self identity and self-esteem with consumer innovativeness. Measures of the research were selected after a detailed literature review on the concepts of consumer innovativeness, hedonic consumption, self identity and self-esteem. After this literature review, measures from the antecedent research were involved in this study. The universe of the research was determined as the students of University of Turin - Italy. In the results, the mean value of self-esteem dimension turned out to be the highest, while the mean value of social identity turned out to be the lowest.. As a results, mean values indicate that consumers are ambivalent about self-esteem and hedonic consumption dimensions. Consumers are closer to disagree with consumer innovativeness and social identity dimensions. Significance values for all three independent variables prooved a significant relationship with consumer innovativenes. Therefore, all three hypothesis of this research which have anticipated a relationship between consumer innovativeness and the concepts of self-esteem, hedonic consumption and social identity have been proven right.

\section{References}

Adarves-Yorno, I. Postmes, T. S. \& Haslam, A. (2007). Creative innovation or crazy irrelevance? The contribution of group norms and social identity to creative behavior. Journal of Experimental Social Psychology No. 43: 410-416

Aizen, I., (1991). The Theory of Planned Behavior, Organizational Behavior and Human Decision Processes, 50(2): 179-211.

Allison, G. (2009). Cross-Cultural Study of Motivation for Consuming Luxuries. PhD Thesis, Lincoln University.

Andriopoulos,C. \& Dawson, P. (2009). Managing Change, Creativity and Innovation. Sage Publications, Great Britain.

Ashforth, B. E. \& Johnson, S. (2001), Which Hat to Wear? The Relative Salience of Multiple Identities in Organizational Contexts. in Hogg, M. A. \& Terry, D. J. (eds). Social Identity Processes in Organizational Contexts. Taylor \& Francis, USA: 31-49.

Banister, E. N. \& Hogg, M. K. (2004). Negative symbolic consumption and consumers' drive for self-esteem: The case of the fashion industry European Journal of Marketing. Vol. 38 No. 7: 850-868.

Batra R \& Ahtola, O. T. (1991). Measuring the hedonic and utilitarian sources of consumer attitudes. Marketing Letters, No. 2 April: 159170.

Berlyne, D.E. (1960). Conflict, arousal and curiosity. McGraw-Hill, NewYork.

Bruwer, J. \& Alant, K. (2009). The hedonic nature of wine tourism consumption: an experiential view. International Journal of Wine Business Research Vol. 21 No. 3: 235-257

Cha, E. S., Kim, K. H. \& Erlen, J. A. (2007). Translation of scales in cross-cultural research: issues and techniques. Journal of Advanced Nursing 58(4): 386-395

Chaudhuri, A. (2002). A study of emotion and reason in products and services. Journal of Consumer Behaviour 1(3): 267-279.

Chitturi, R, Raghunathan, R. \& Mahajan V. (2007). Form versus function: how the intensities of specific emotions evoked in functional versus hedonic trade-offs mediate product preferences. Journal of Marketing Research, No. 44(November): 702-714.

Churchill, G.A.Jr., \& lacobucci, D. (2002). Marketing research - methodological foundations (8th ed.). Australia: South-Western Thomson Learning.

Clark, R. A. \& Goldsmith, R. E. (2005). Market Mavens: Psychological Influences. Psychology \& Marketing, Vol. 22 (4): 289-312,

Daghfous, N., Petrof, J. V. ve Pons, F. (1999). Values and Adoption of Innovations: Accross Cultural Study. Journal of Consumer Marketing, 16(14): 314-331.

Davis, F.D., (1989). Perceived Usefulness, Perceived Ease of Use, and User Acceptance of Information Technology. MIS Quarterly, 13(3): $319-340$.

Dhar, R., \& Wertenbroch, K. (2000). Consumer choice between hedonic and utilitarian goods. Journal of Marketing Research, No. 37: 60-71.

Dubois, B., Czellar, S. \& Laurent, G. (2005). Consumer Segments Based on Attitudes Toward Luxury: Empirical Evidence from Twenty Countries. Marketing Letters 16/2: 115-128

Ellemers, N., Gilder, D. \& Haslam S. A. (2004). Motivating and Groups atWork: A Social Identity Perspective on Leadership and Group Performance. Academy of Management Review, 29 (3): 459-78.

Emler, N. (2001). The cost and cause of low self-esteem. Website: http://www.jrf.org.uk/knowledge/findings/socialpolicy/n71.asp, Retrieved April 2013.

Erdoğan, I.., (1998). Araştırma Dizaynı Ve İstatistik Yöntemleri, Emel Matbaası, Ankara.

Fishbein, M. \& Ajzen, I. (1975). Belief, Attitude, Intention And Behavior: An Introduction To Theory And Research, Addison-Wesley Reading, Boston.

Forehand, M. R. \& Deshpandé, R. (2001). "What we see makes us who we are: Priming ethnic self-awareness and advertising response," Journal of Marketing Research, 38 (3): 336-348.

Glanz, K. (2008). "Diffusion of Innovations". p. 313-330. In: Glanz, K., Rimer, B, Viswanath, K. (eds.) Health Behavior and Health Education Theory, Research and Practice. John Wiley\&Sons, San Francisco. 
Goldsmith, R. E. \& Hofacker, C., (1991). Measuring Consumer Innovativeness, Journal of the Academy of Marketing Science, No. 19:1004-1016

Greenhalgh, T., Robert, G., Macfarlane, F., Bate, P. \& Kyriakadou, O. (2004). Diffusion of Innovations in Service Organisations: Systematic Review and Recommendations. Milbank Quarterly, No. 82: 581-629.

Grewal, R., Mehta, R. \& Kardes, F.R. (2000). The role of the social-identity function of attitudes in consumer innovativeness and opinion leadership, Journal of Economic Psychology, No. 21: 233-252.

Hair, J.F.Jr., Money, A.H., Samouel, P., \& Page, M. (2007). Research methods of business. West Sussex: John Wiley \& Sons Ltd. Hair, J.F.Jr., Money, A.H., Samouel, P., \& Page, M. (2007). Research methods of business. West Sussex: John Wiley \& Sons Ltd.

Hagtvedt, H., \& Patrick, V. M. (2009). The broad embrace of luxury: Hedonic potential as a driver of brand extendibility. Journal of Consumer Psychology, No. 19: 608-618.

Highhouse, S., Thornbury, E.E. \& Little, I.S. (2007). Social-identity functions of attraction to organizations. Organizational Behavior and Human Decision Processes, No. 103: 134-146.

Hirschman, E.C. \& Holbrook, M.B. (1982). Hedonic consumption: emerging concepts, methods and Propositions. The Journal of Marketing, Vol. 46 No. 3: 92-101.

Hopkinson, G. C. \& Pujari, D. (1999). A factor analytic study of the sources of meaning in hedonic consumption. European Journal of Marketing,Vol. 33 No. 3/4: 273-290.

Hugstad, P., Taylor, J.W. \& Bruce, G.D. (1987). Effects of Social Class on Consumer Information Search, Journal of Consumer Marketing, No. 4: 41-46.

Iftar, G.K., (2000). Bilimsel Araştırma Yöntemleri, http://bde.anadolu.edu.tr/ (http://193.140.21.192:8000/SCRIPT/bay2/scripts/student Iserv_page.pl?970127244+bay0401.html, Retrieved January 2013.

Jacobs, H. (2013). Co-innovation through multiple social identity processes. The story of a South African co-op owned business. European Business Review Vol. 25 No. 1: 42-64.

Jaffe, Lynn J. \& Paul D. Berger (1988). Impact on purchase intent of sex-role identity and product positioning. Psychology and Marketing, 5(3) (Fall): 259-271.

Lamb, C. W., Hair, J.F. \& McDaniel, C. D. (2012). Essentials of Marketing. South-Western Cengage Learning, USA.

Lane, R. E. (1995). The Market Experience. Cambridge University Press, USA.

Lim, E. \& Ang, S. (2008). Hedonic vs. utilitarian consumption: A cross-cultural perspective based on cultural conditioning. Journal of Business Research No. 61: 225-232.

Lynn, M., \& Gelb, B. D. (1996). Identifying innovative national markets for technical consumer goods. International Marketing Review, 13(6): 43-57.

Maleki M., (2000). Low Self-Esteem. Counseling and Learning Skills Services (CALSS) Website: http:/lwww.calss.utoronto.cal pamphlets/low_self_esteem.htm, Retrieved April 2013.

Massimo, B. \& Bagozzi, R. (2000). Self-Categorization, Affective Commitment, and Group Self-Esteem as Distinct Aspects of Social Identity in the Organization. British Journal of Social Psychology, 39 (4): 555-77.

Miao, L., Lehto, X. \& Wei, M.S. (2013): The Hedonic Value of Hospitality Consumption: Evidence from Spring Break Experiences, Journal of Hospitality.Marketing \& Management, DOI:10.1080/19368623.2013.766582

Miao, L., Lehto, X. \& Wei, W. (2011). The Hedonic Experience of Travel-Related Consumption. International

Nunnally, J.C.Jr. (1978). Psychometric theory, New York: McGraw-Hill Book Company.

Nunnally, J.C.Jr., \& Bernstein, I.H. (1994). Psychometric theory (3rd ed.). New York: McGraw-Hill Book Company.

Okada, E. M. (2005). Justification effects on consumer choice of hedonic and utilitarian goods. Journal of Marketing Research, No.42: 43-53.

Pride, W. M. \& Ferrell, O.C. (2007). Foundations of Marketing. Second Edition. Houghton Mifflin Company, USA.

Reed, A. \& Forhand, M.(2003): Social Identity in Marketing Research. An Integrative Framework. Manuscript, submitted for publication. Website: http://qbox.wharton.upenn.edu/documents/mktg/research/Simktstrategy-ar14.pdf, Retrieved: March 2013.

Roehrich, G. (2004). Consumer innovativeness: Concepts and measurements Journal of Business Research No. 57: 671- 677.

Rogers, E. M. (2003). Diffusion of Innovations. (5th ed.): Free Pres, New York.

Rogers, E. M. (1995). Diffusion of innovations (4th ed.). The Free Pres, New York.

Roy, R. \& NG, S. (2012). Regulatory focus and preference reversal between hedonic and utilitarian consumption Journal of Consumer Behaviour, No. 11: 81-88.

Saxe, R., \& Weitz, B.A. (1982). The SOCO scale: A measure of the customer orientation of salespeople, Journal of Marketing Research, 19(3), 343-351.

Shavitt, S. \& Nelson, M.R. (2000), "The social- identity function in person perception: Communicated meanings of product preferences". pp. 37-57. In Gregory Maio and James M. Olson, Mahwah (eds.). Why we evaluate: Functions of attitudes. NJ: Lawrence Erlbaum Associates.

Silverman, G. (2011). The Secrets of Word of Mouth Marketing. 2nd edition, Amacon, USA.

Sipahi, B., Yurtkoru, E.S., Çinko, M., (2008). Sosyal Bilimlerde SPSS ile Veri Analizi, İstanbul: Beta Yayınları

Snell, J., Gibbs, B., and Varey, C. (1995). Intuitive hedonics: Consumer beliefs about the dynamics of liking". Journal of Consumer Psychology, 4(1): 33-60.

Stoddard, J. E., Evans, M. \& Shao, X. (2012). Marketing Arts and Crafts: Exploring the Connection Between Hedonic Consumption, Distribution Channels, and Tourism. International Journal of Hospitality \& Tourism Administration, No. 13: 95-108. 
Surry, D.W. \& Farquhar, J.D. (May 1997) Diffusion theory and instructional technology. Journal of Instructional Science and Technology (2) 1.

Tabachnick, B.G., \& Fidell, L.S. (1996). Using multivariate statistics (3rd ed.). New York: Harper Collins College Publishers.

Tajfel, H. (1972). Social categorization. English manuscript of "La cate'gorisation sociale." In S. Moscovici (Ed.), Introduction a` la psychologie sociale (Vol. 1, pp. 272-302). Paris, Larousse.

Tifferet, S. \& Herstein, R. (2012). Gender differences in brand commitment, impulse buying, and hedonic consumption. Journal of Product \& Brand Management, 21/3: 176-182

Truong, Y. \& McColl, R. (2011). Intrinsic motivations, self-esteem,andluxurygoodsconsumption. Journal of Retailing and Consumer Services, No. 18: $555-561$.

Urminsky, O. \& Kivetz, R. (2003). Reconciling Impulsiveness with Self-Control: Explaining Differential Impatience toward Hedonic andUtilitarian Consumption. Advances in Consumer Research, Volume 31: 358-361.

Venkatesan, M.(1973). Cognitive consistency and novelty seeking. In: Ward S. \& Robertson T.S., (eds.) Consumer behavior-theoretical sources. Prentice Hall, Englewood Cliffs.

Vigneron, F.\& Johnson L. (1999). A Review and a Conceptual Framework of Prestige. Academy of Marketing Science Review Volume, No. 1, Website: http://www.amsreview.org/articles/vigneron01-1999.pdf.

Waarts, E. \& Van Everdingen, Y. (2005). The Influence of National Culture on the Adoption Status of Innovations:: An Empirical Study of Firms Across Europe. European Management Journal, Volume 23, Issue 6: 601-610

Wejnert, B. (2002). Integrating Models of Diffusion of Innovations: A Conceptual Framework. Annual Review of Sociology, No. 28: 297326.

Wieseke, J., Ahearne, M., Lam, S. K. \& Dick, R. (2008). The Role Of Leaders In Internal Marketıng Journal of Marketing, Article Postprint, Website: http://ssrn.com/abstract=1584725, Retrieved April 2013.

Wooten, David B. (1995). One-of-a-kind in a full house: Some consequences of ethnic and gender distinctiveness. Journal of Consumer Psychology, 4 (3): 205-224.

Zhong, J.Y. \& Mitchell, V. (2010). A mechanism model of the effect of hedonic product consumption on well-being. Journal of Consumer Psychology No. 20:152-162 www.thefreedictionary.com, Retrieved March 2013. 